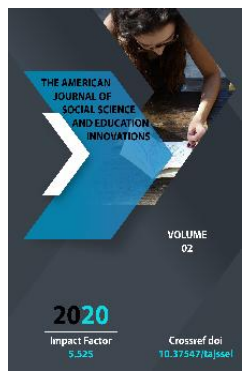

\title{
Policy Of The Russian Empire In Responsible Population In Turkestan: Causes And Consequences
}

\author{
Dzhuraev Husniddin Pazliddinovich \\ Lecturer At The Department Of History Of Uzbekistan, Fergana State University, Uzbekistan
}

Journal Website:

http://usajournalshub.c

om/index,php/tajssei

Copyright: Original

content from this work

may be used under the

terms of the creative

commons attributes

4.0 licence.

\section{ABSTRACT}

This article explores the employment and economic issues of Russian populations and villages in Turkestan as a result of the Russian government's resettlement policy, based on "Turkestan Collection» and periodicals.

\section{KEYWORDS}

Resettlement Russian settlement, settlement, village, farming, livestock, beekeeping, horticulture, melon growing, new crop, cotton, cereals, land funds, rain-fed lands, artificial irrigation.

\section{INTRODUCTION}

The fact is that in the Russian Empire, the policy of resettlement of the Russian population to our region has been little studied; therefore an objective assessment of these political processes is also important. The policy of the Russian tsarist deportation of Russian peasants to Turkestan in the late 19th and early 2oth centuries is a complex series of unexplored studies.

Moreover, the Russian resettlement policy posed various problems in Turkestan in the socio-political sphere, negatively affecting the material and spiritual life of the local population, and the emergence of various 
obstacles to the colonialism of Islam required new study.

An analysis of sources shows that the population of Turkestan has increased several times from the 1990s to the First World War. It can be concluded that population growth is the result of natural growth, on the one hand, and the influx of people from other countries into the valley. As a result of the resettlement policy of tsarist Russia, many categories of people migrated from Russia to Turkestan for permanent residence [2].

The resettlement policy was to create strong Russian villages in the country, create a culture of agriculture and modern industry based on it. In addition, the goal was to increase income from agriculture, develop new land by strengthening the irrigation system and transferring land to the state treasury. And multifaceted goals, such as the creation of new land funds through the Kyrgyz settlement, an increase in the export of raw materials from the country, were planned in parallel with the interests of the capital region. However, the collection notes that the displaced people handed over their land to local farmers, went to work in the city on the railways and, if possible, moved to industrial areas.

According to the collection, the overmixed can be divided into three groups. The first group consisted of military men and Cossacks, who rented their land, while they themselves worked as hired workers, salesmen in shops, employees in production offices. The older generation was engaged in livestock and poultry farming, and produced meat and milk for the market. The second group includes dehkans from the South Russian Gubernia. They mastered the culture of artificial irrigation and dry farming. They lived first in basements, and later started building houses. The third group includes the rich and well-off households. They plowed the horse with a plug. They used the latest technology such as weeding and assembly machines, and they became economically stronger in 2-3 years.

\section{MATERIALS AND METHODS}

Many articles in the "Turkestan collection» contain information on the composition of the population of Turkestan, the customs of various nationalities, their professions, professions and problems associated with farming on agricultural lands. The study of the ethnic composition of the Turkestan population by Russian researchers at the beginning of the 2oth century is reflected in the Turkestan collection. As we look more closely at the above information in the collection, we draw the following conclusions. That is, as a result of the resettlement policy of tsarist Russia at the end of the 19th and the beginning of the 2oth centuries, it can be said that periods of dramatic changes in ethnodynamic processes occurred in Turkestan compared to the millennium. Now the new influx has had a profound impact on agriculture, industry, culture and other industries.

At the end of the 19th and the beginning of the 2oth centuries, the Russian-speaking population of the Fergana Valley increased sharply due to the influx of other ethnic groups. One of the main reasons for this was the policy of the Russian Empire to resettle the Russian population to Turkestan. In particular, the colonization of Turkestan is the result of the conquest of the region by the Russian capitalists.

The migration policy of the Russian Empire was also associated with a number of political and socio-economic reasons. Strengthening 
the influence of the Russian population should serve to strengthen the rule of tsarist Russia here. Resettlement of Russian peasants from the central provinces to foreign lands in order to alleviate social tensions between them and prevent peasant anger. In addition, periodic inferiority and famine in Central Russia led to the spontaneous migration of the Russian population to remote countries, including the Fergana Valley.

\section{RESULT AND DISCUSSION}

From the beginning of the twentieth century until the First World War, the Russian Empire initially moved the military, landless farmers, and then other professions, including the unemployed, in general, various people, even criminal groups, began to migrate to Turkestan. Among them were workers, intellectuals, entrepreneurs, businessmen, as well as people who came to strive for an easy life [4].

Russian settlers settled in cities and villages, and new settlements were established in some areas. Since the Russians were the dominant nation in the empire, the government paid close attention to the fact that their living conditions were better than those of other indigenous peoples. Even many Russian peasants who came here were able to rebuild themselves or even increase their wealth with the help of the government.

Materials published in the «Turkestan collection" contain extensive information in various directions. It should be noted that during the time of tsarist Russia, modern settlements and industrial cities appeared. It should also be noted that in the period under review, the emergence and development of industrial enterprises led to an increase in the population and the emergence of local entrepreneurs, small enterprises. In addition, population growth was influenced by factors such as herd migration policies, increased influx of other European countries and the creation of military fortifications [4.3].

\section{CONCLUSION}

Thus, various materials from the «Turkestan Collection» provide extensive information about the ethnodynamics of the population of Turkestan and the changes that have occurred in its socio-economic life.

\section{REFERENCES}

1. Jabborov M., R. Arslonzoda, Sh. Gafforov. Russia's policy on resettlement of the population to Turkestan (on the example of the Fergana Valley) // FDU. Science news. - Fergana, 2000. - No. 1-4; Turkestan warehouse. - P. 249. // Statistical review of the Fergana region for 1913 - Skobelev. $-1916$.

2. Free migration business, Turkestan courier. -1909, No. 108. // TS. -P. 508.

3. Statistical review of the Ferhana region for 1913 - Skobelev. -1916. -P. 25 